\title{
Roads in the Southwestern Amazon, State of Acre, between 2007 and 2019
}

\author{
Eric de Souza Nascimento ${ }^{1}$, Sonaira Souza da Silva ${ }^{1, *(\mathbb{D})}$, Leandra Bordignon ${ }^{1}$ (D), \\ Antonio Willian Flores de Melo ${ }^{1}\left(\mathbb{D}\right.$, Amintas Brandão Jr. ${ }^{2,3}{ }^{(D}$, Carlos M. Souza Jr. ${ }^{2}$ and \\ Celso H. L. Silva Junior 4,5 (D)
}

Citation: Nascimento, E.d.S.; Silva, S.S.d.; Bordignon, L.; Melo, A.W.F.d.; Brandão, A., Jr.; Souza, C.M., Jr.; Silva Junior, C.H.L. Roads in the Southwestern Amazon, State of Acre, between 2007 and 2019. Land 2021, 10, 106. https://doi.org/10.3390/ land10020106

Received: 18 November 2020

Accepted: 18 January 2021

Published: 23 January 2021

Publisher's Note: MDPI stays neutra with regard to jurisdictional claims in published maps and institutional affiliations.

Copyright: (c) 2021 by the authors. Licensee MDPI, Basel, Switzerland. This article is an open access article distributed under the terms and conditions of the Creative Commons Attribution (CC BY) license (https:/ / creativecommons.org/licenses/by/ $4.0 /)$
1 Geoprocessing Laboratory Applied to the Environment (LabGAMA), Universidade Federal do Acre-UFAC, Cruzeiro do Sul, AC 69980-000, Brazil; eric.nascimento@sou.ufac.br (E.d.S.N.); leandra.bordignon@ufac.br (L.B.); willian.flores@ufac.br (A.W.F.d.M.)

2 Instituto do Homem e Meio Ambiente da Amazônia-IMAZON, Belém, PA 66055-200, Brazil; brandaojr@imazon.org.br (A.B.J.); souzajr@imazon.org.br (C.M.S.J.)

3 Center for Sustainability and the Global Environment (SAGE), Nelson Institute for Environmental Studies, University of Wisconsin-Madison, Madison, WI 53726, USA

4 Tropical Ecosystems and Environmental Sciences Laboratory (TREES), National Institute for Space Research-INPE, São José dos Campos, SP 12227-010, Brazil; celso.junior@inpe.br

5 Departamento de Engenharia Agrícola (DEA), Universidade Estadual do Maranhão-UEMA, São Luís, MA 65055-310, Brazil

* Correspondence: sonaira.silva@ufac.br

Abstract: Over the past 40 years, roads have been the main driver behind the State of Acre's occupation and development. However, the expansion of roads, has often been associated with the advance of deforestation, habitat fragmentation, and social conflicts. There are no up-to-date data available on the current extent of Acre's road network nor its environmental and socioenvironmental impacts. In this study, we updated the State of Acre's road network map for the period 2007 to 2019 through the visual interpretation of 153 Landsat images $(5,7$, and 8$)$ at a scale of 1:50,000. To estimate the impact of roads, we measured the distribution of roads in municipalities and in different land tenure categories and calculated the correlation between roads and annual deforestation. Up to 2019 , we estimated $19,620 \mathrm{~km}$ of roads, of which $92 \%$ were unofficial roads, $6 \%$ federal roads, and $2 \%$ state roads. The roads increased at an average annual rate of $590 \mathrm{~km} \mathrm{year}^{-1}$. The most significant advance in road length between 2007 and 2019 was in protected areas (240\%), followed by public lands (68\%) and settlement projects $(66 \%)$. We recommend monitoring of the road network to understand the landscape's evolution and support actions against illicit environmental and socioenvironmental impacts.

Keywords: highways; deforestation; remote sensing; land-tenure; protected areas

\section{Introduction}

Historically, the Amazon occupation occurred along rivers and roads, which facilitated the transportation of people and cargo, but roads are also one of the main drivers of deforestation in the region [1-3]. The Brazilian Federal Government built highways in the Amazon with a strategy of land integration and infrastructure for transportation of commodities (BR-163-Cuiabá-Santarém, BR-230-Transamazônica Pará/Amazonas, BR-319-Porto Velho/Rondônia-Manaus/Amazonas) from the 1960s through to the 1980s. Government programs initiated in the 1990s, such as the Brazil in Action program (Programa Brasil em Ação), followed by the Advance Brazil Program (Programa Avança Brasil), and the Program for the Acceleration of Growth (PAC-Programa de Aceleração do Crescimento) aimed at economic growth, boosted the expansion of the network of roads in the Amazon [4,5]. These roads favored the migration of people from various parts of Brazil, which has led to the intensification of logging, deforestation, fires, and expansion of the 
agricultural frontier [6-8]. These roads have been pointed out as the most significant drivers of deforestation and fires in the Amazon [6,9-11].

Road construction in the Amazon is still a dilemma [12]. Roads bring social and economic benefits to the region, such as increasing the accessibility of agriculture and industrial products, electricity, and essential public services (e.g., education and health). Roads also enable significant environmental and social impacts, such as deforestation and fires, the influx of exotic species, hunting, illegal logging, and the rise of diseases and criminality. Even major roads such as BR-319, BR-163, and BR-230 lack development plans that reconcile social, economic, and environmental issues [10,12]. The continuous pursuit of an ecological-social-economic balance is needed to diminish the environmental impacts that compromise regional social development [11].

Brandão Jr and Souza Jr [13] identified that two types of roads are predominant in the Amazon: official and unofficial roads. Official roads are extensive roads built mainly by the Federal Government in the 1970s to interconnect the region to the rest of Brazil. Unofficial roads were mostly built by the private sector to explore and access natural resources in the Amazon. Often, unofficial roads do not appear on official maps of the National Department of Transportation and Infrastructure (DNIT—Departamento Nacional de Infraestrutura de Transportes) and the Brazilian Institute of Geography and Statistics (IBGE-Instituto Brasileiro de Geografia e Estatística).

The road extraction from remote sensing images is still a challenge, which depends on the spectral and/or spatial resolution of the images and the road's infrastruture (diverse road material and complex backgrounds-urban or rural), which affect the mapping method [14]. Automatic or semi-automatic mapping methods are based on high spatial resolution images, which have a high cost and low temporal availability [15-17]. Road mapping in the tropical forest, when there is an objective of temporal and spatial analysis (regional, state, or municipal level), still uses manual mapping methods $[13,18,19]$.

Vicinal roads or agro-roads, subtypes of unofficial roads, also occur in the region. They are the driving force behind the expansion of new fronts of deforestation, irregular occupation, fires, and illegal logging, and require constant monitoring of their emergence to combat illegal environmental activities. In the State of Pará, unofficial roads almost doubled between 1996 and 2001 [13]. In the State of Acre, Nascimento et al. [20] showed increases of up to $412 \%$ between 2000 and 2014 . However, there is a lack of detailed analysis on the expansion and impacts of roads in the State of Acre and their spatio-temporal dynamics, limiting the understanding of the regions most affected by road growth and the relationship of these roads with deforestation. Our goal is to map the expansion of roads in the State of Acre to understand their spatio-temporal dynamics and their impact on the forest cover. To this end, we propose to answer the following questions: (1) What is the annual growth rate of roads in the State of Acre from 2007 to 2019? (2) Which municipalities and land categories have the highest total length of roads in Acre? (3) What is the correlation between roads and deforestation (forest clear-cutting)?

\section{Materials and Methods}

\subsection{Characterization of the Study Area}

The study area is the State of Acre in the southwestern Amazon (Figure 1). The boundaries of the State of Acre are formed by international frontiers with Peru (West) and Bolivia (South), and state boundaries with Amazonas (North) and Rondônia (East). With a total area of $164,422 \mathrm{~km}^{2}$, twice the size of Ireland, the State is divided into 22 municipalities (Figure 1). Approximately $63 \%\left(101,645 \mathrm{~km}^{2}\right)$ of its territory is covered by protected areas, consisting of Conservation Units (Federal, State, and Municipal) with $48 \%\left(77,744 \mathrm{~km}^{2}\right)$ and Indigenous Lands with 15\% $\left(23,901 \mathrm{~km}^{2}\right)$ [14]. Additionally, almost $10 \%\left(15,039 \mathrm{~km}^{2}\right)$ of the State was deforested by 2019, the sixth-highest among Brazilian Amazon states [21]. 


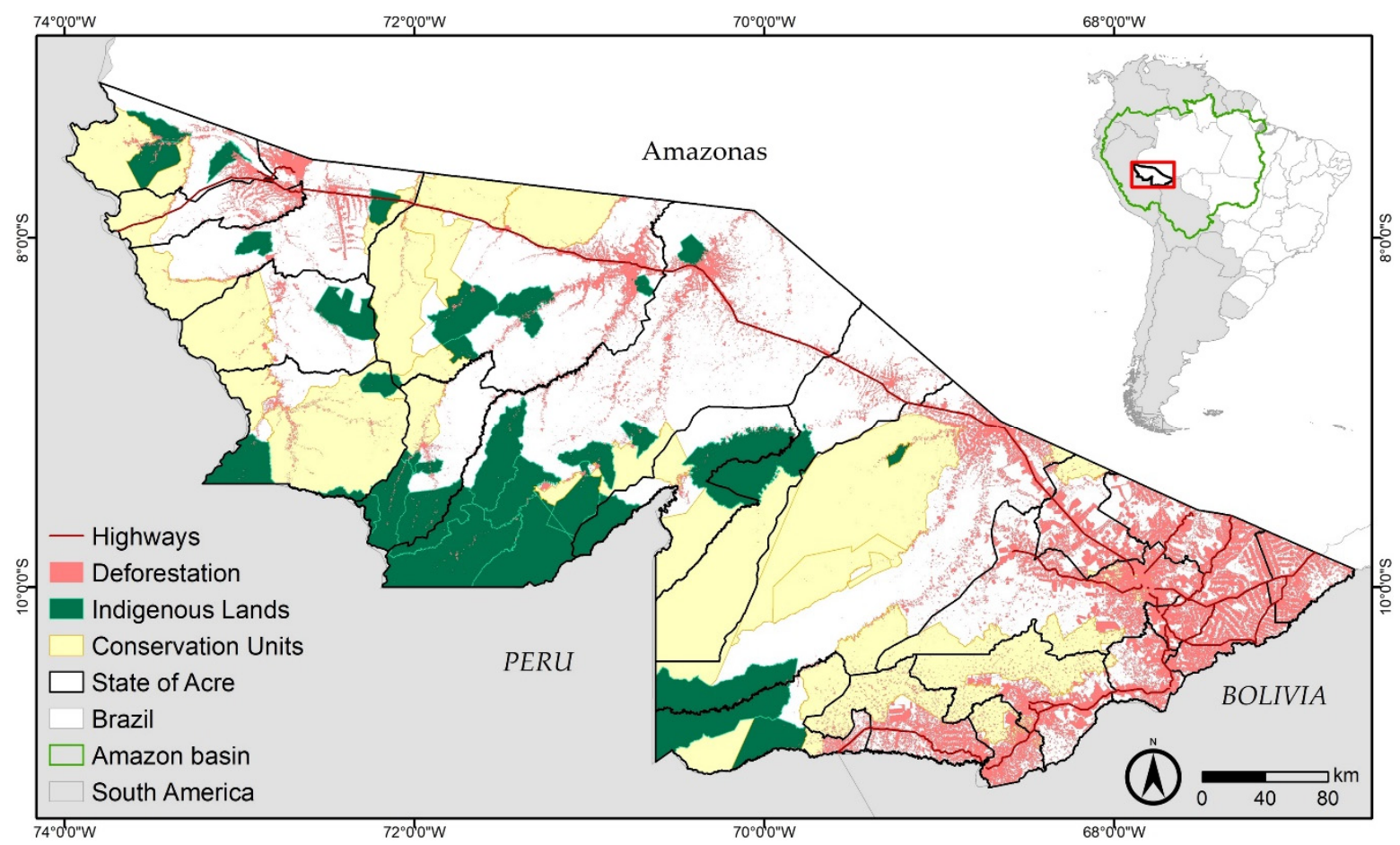

Figure 1. Study area with indigenous lands, conservation units, and deforestation areas in the State of Acre, Brazil in 2019.

\subsection{Road Identification, Mapping, and Analysis}

We identified and mapped the roads in the State of Acre from 2007 to 2019 based on the visual interpretation and digitalization of roads detected in Landsat satellite images, at a scale of 1:50,000 (Figure 2). We analyzed 153 Landsat images from TM (Thematic Mapper) and OLI (Operational Land Imager) sensors from June to December, to minimize occurrence of clouds. The images were accessed from the United States Geological Survey (USGS). We used the blue, green, and red bands (Landsat 5 and 7 with bands 1-2-3 and Landsat 8 with bands 2-3-4) to identify the roads (Supplementary Material Table S1). The contrast of reflectance between the exposed soil of the road with different land uses (forest, pasture, and/or water bodies) served to delineate the roads.

The Ecological Economic Zoning of the State of Acre for 2006 and the Rural Environmental Registry (CAR-Cadastro Ambiental Rural) of 2014 served as baseline mapping. All the roads visualized in the 2006 Landsat image indicate that roads exist until this date, without the definition of the date of visualization. With this database for 2007-2014, we segmented the lines (roads) as the roads are visualized in the Landsat images. For the period from 2015 to 2019, the roads viewed in the Landsat images were scanned manually, with identification of the year of view (Figure 2).

The validation of the road mapping was carried out from the random drawing of 2000 points within a range of $10 \mathrm{~m}$ from road axes and 10,000 random points in four sample regions of $27,000 \mathrm{~km}^{2}$. We used Planet satellite images with a spatial resolution of $3 \mathrm{~m}$ as references (https:/ / www.planet.com/nicfi). The Kappa coefficient served to estimate the overall mapping accuracy [22]. 

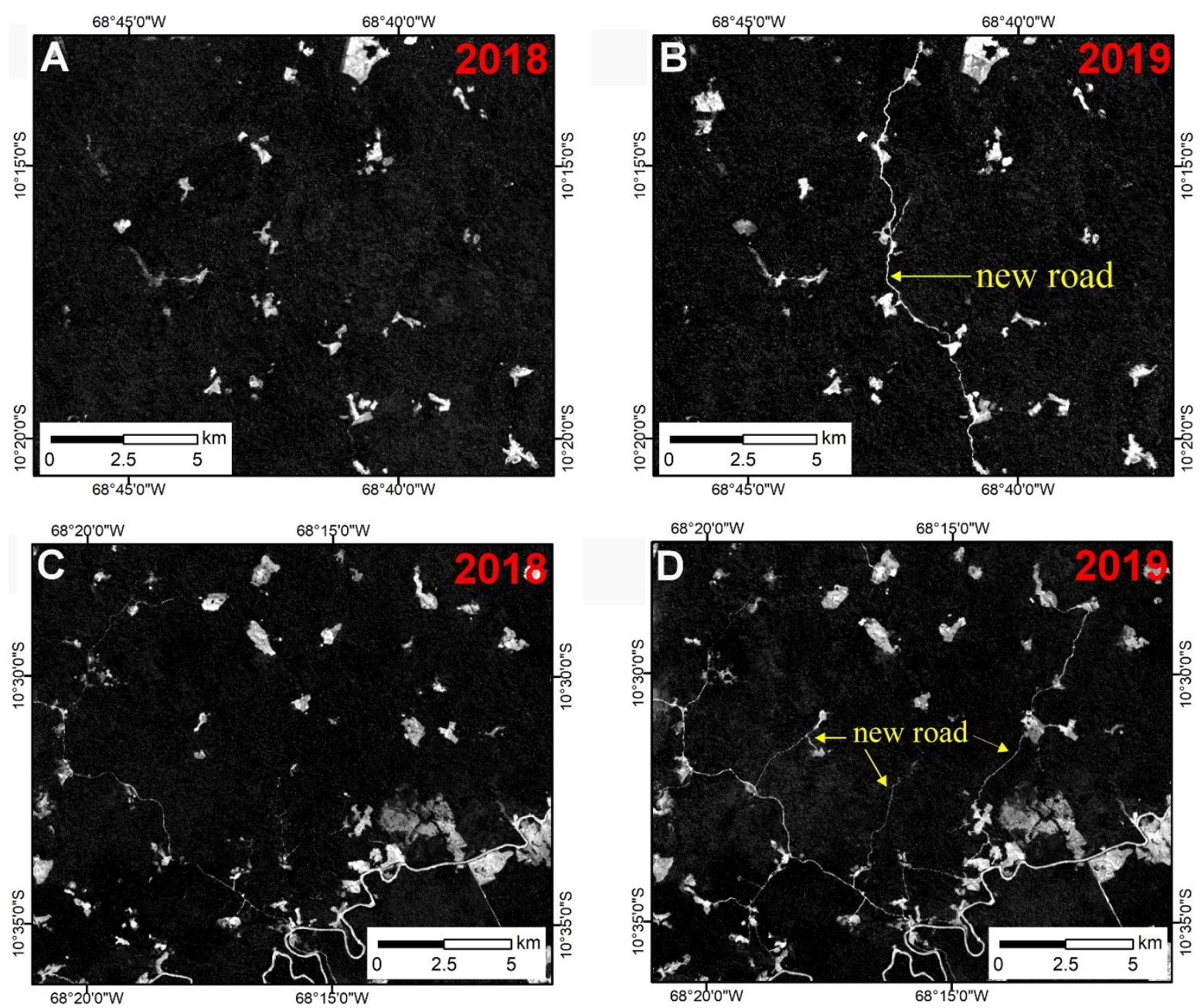

Figure 2. Example of roads visible in the Landsat-8 band 4 (red) images for the years 2018 (A,C) and 2019 (B,D).

\subsection{Road Growth Characterization in Terms of Land-Tenure and Municipalities}

We used two databases to understand the dynamics of the growth of road extensions by land-tenure and municipalities. The first was the land base of the 2010 Ecological Economic Zoning (ZEE-Zoneamento Ecológico Econômico) [23]. The classes considered in the ZEE were: Conservation Units, Indigenous Lands, Settlement Projects, Private Properties, and Public Land. The second was the base of official municipal limits of IBGE updated for 2015 [24].

\subsection{Relationship of Roads and Deforestation}

We analyzed the spatio-temporal relationship between the length of roads and forest loss (forest clear-cutting) based on the deforestation data from the Project for Monitoring Deforestation in the Legal Amazon (PRODES - Programa de Monitoramento da Floresta Amazônica Brasileira por Satélite) maintained by the Brazilian National Institute for Space Research (INPE-Intituto Nacional de Pesquisas Espaciais) [21]. The INPE makes annual deforestation data available to the State, which was studied at different spatial scales. We analyzed the relationship between road and deforestation at four scales: state, municipalities, land-tenure, and buffers up to $50 \mathrm{~km}$ along the road. To understand the relationship between roads and accumulated deforestation until 2019, we used the municipality limit as a sample spatial clipping unit. To analyze the road distance buffers, we used critical thresholds of $50 \%$ and $95 \%$ deforestation along the roads to understand forest protection level considering the entire State of Acre and the Conservation Units. This analysis serves 
as a predictor of the dynamics of roads versus deforestation for new roads in Acre. We used correlation and regression analysis to evaluate the strength of the relationship between roads and deforestation.

\section{Results}

\subsection{Roads in Acre}

We identified $19,620 \mathrm{~km}$ of roads by 2019 , with $17,983 \mathrm{~km}$ of official and unofficial roads ( $92 \%$ of the total), $1247 \mathrm{~km}$ of federal highways ( $6 \%$ of the total), and $390 \mathrm{~km}$ of state highways (2\% of the total) (Figure 3A). From 2007 to 2019, the roads increased by $7665 \mathrm{~km}$, representing $39 \%$ of the total road extent. The overall accuracy of road mapping in Acre was $98 \%$, considering Planet images as a reference. We did not identify 266 stretches or $439 \mathrm{~km}$ of roads on the official CAR base until 2014, thus being defined as "unidentified". These stretches were visible before 2007, but in the 12 years evaluated, these pathways were no longer visible in Landsat images.

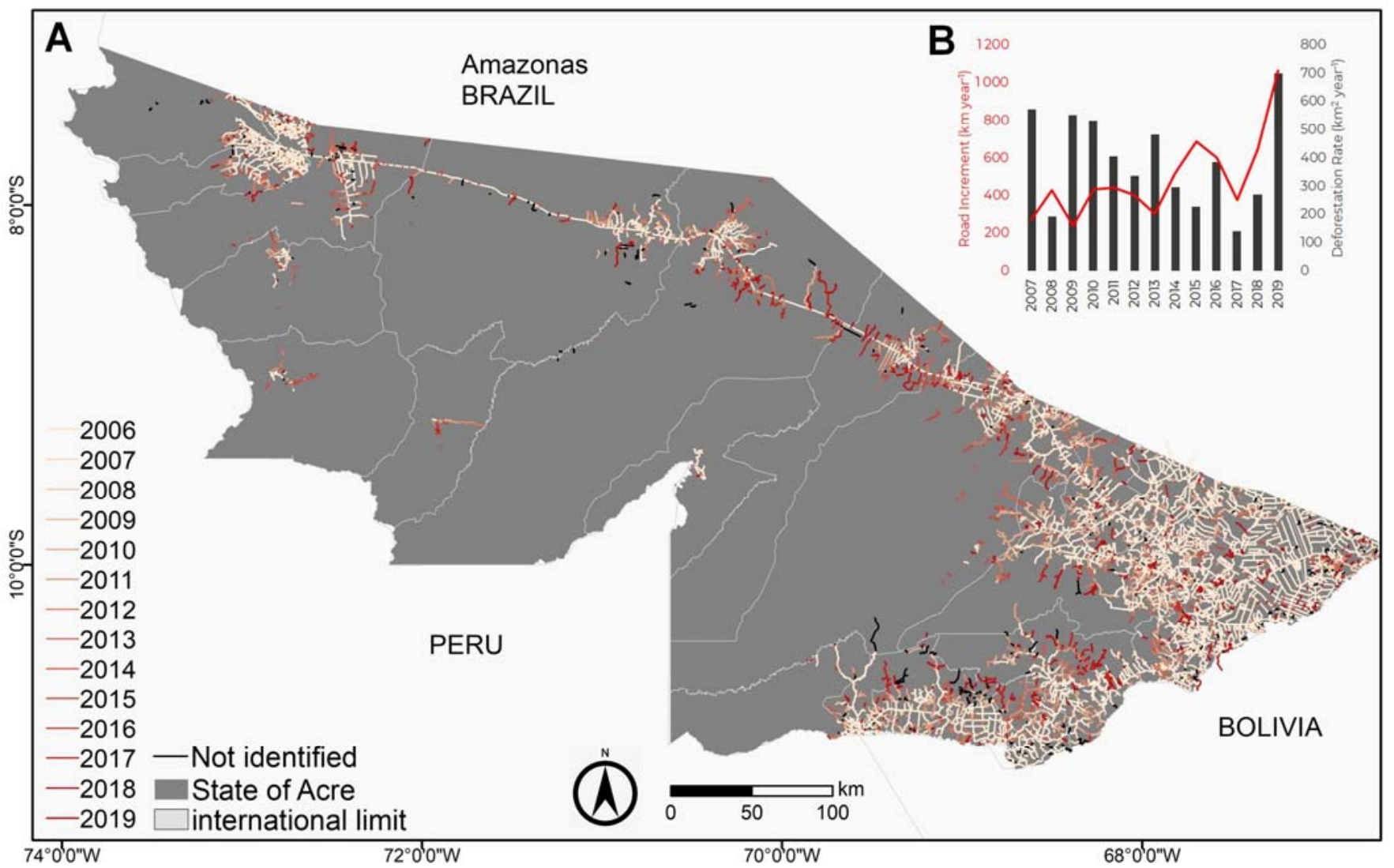

Figure 3. (A) Spatial-temporal distribution of roads in the State of Acre. (B) Annual increment of roads and deforestation in the State of Acre from 2007 to 2019.

Roads are present in all 22 municipalities in Acre, and most of the local roads (87.9\%) are directly and indirectly connected to federal highways (BR-307, BR-317, BR-364) and state highways (AC-40, AC-99, AC-400, AC-405). Exceptions to this trend can be found in Porto Walter, Marechal Thaumaturgo, Jordão, and Santa Rosa do Purus, where no road is connected to federal or state highways. These roads demonstrate the isolation of these municipalities, which have waterways and airways as their main transportation access. In the 12 years evaluated, the average annual increase was $590 \mathrm{~km}_{\text {year }}{ }^{-1}$. The year with the highest increment of roads was 2019 , with $1050 \mathrm{~km}$, followed by $2007(863 \mathrm{~km})$, $2009(830 \mathrm{~km}), 2013(726 \mathrm{~km})$, and $2016(580 \mathrm{~km})$, representing peaks every three years (Figure 3B). Over time, there was a downward trend in the annual growth rate of roads until 2019, the year with the largest annual increase. 


\subsection{Distribution of Roads among the Municipalities of Acre}

Of the 22 municipalities in Acre, the one with the largest extension and annual increase in roads is the capital, Rio Branco, with $2669 \mathrm{~km}$ and $95 \mathrm{~km}_{\text {year }}^{-1}$, followed by Sena Madureira and Xapuri, with 1587 and $1406 \mathrm{~km}$, and with 73 and $56 \mathrm{~km}_{\text {year }}{ }^{-1}$, respectively (Table 1). Regarding roads' density by the municipal area, Acrelândia, Senador Guiomar, and Capixaba have the highest densities, with $0.56,0.53$, and $0.51 \mathrm{~km} \mathrm{~km}^{-2}$, respectively. The municipality of Jordão increased the length of all roads by $95 \%$ in 2007-2019.

Table 1. The total length of roads, density, and annual increment by municipality of the State of Acre for the period 2007-2019. The list of municipalities is ranked by the highest total length of roads.

\begin{tabular}{|c|c|c|c|c|c|}
\hline Municipality & Municipality Area $\left(\mathrm{km}^{2}\right)$ & Total Length of Roads (km) & Length 2007-2019 (km) & Density $\left(\mathbf{k m ~ k m}^{-2}\right)$ & Annual Increment (km) \\
\hline Rio Branco & 8830 & 2669 & 1146 & 0.30 & 95 \\
\hline $\begin{array}{c}\text { Sena } \\
\text { Madureira }\end{array}$ & 23,737 & 1587 & 944 & 0.07 & 73 \\
\hline Xapuri & 5344 & 1406 & 725 & 0.26 & 56 \\
\hline Bujari & 3033 & 1268 & 531 & 0.42 & 41 \\
\hline Brasiléia & 3913 & 1249 & 548 & 0.32 & 42 \\
\hline $\begin{array}{l}\text { Senador } \\
\text { Guiomard }\end{array}$ & 2321 & 1235 & 151 & 0.53 & 12 \\
\hline Porto Acre & 2604 & 1176 & 229 & 0.45 & 18 \\
\hline $\begin{array}{l}\text { Cruzeiro do } \\
\text { Sul }\end{array}$ & 8810 & 1113 & 375 & 0.13 & 29 \\
\hline $\begin{array}{l}\text { Plácido de } \\
\text { Castro }\end{array}$ & 1943 & 1106 & 148 & 0.57 & 11 \\
\hline Feijó & 27,982 & 1057 & 636 & 0.04 & 49 \\
\hline Acrelândia & 1809 & 1018 & 232 & 0.56 & 18 \\
\hline Capixaba & 1702 & 873 & 306 & 0.51 & 24 \\
\hline Epitaciolândia & 1654 & 756 & 301 & 0.46 & 23 \\
\hline Tarauacá & 20,192 & 744 & 300 & 0.04 & 23 \\
\hline $\begin{array}{l}\text { Rodrigues } \\
\text { Alves }\end{array}$ & 3091 & 677 & 224 & 0.22 & 17 \\
\hline $\begin{array}{l}\text { Manoel } \\
\text { Urbano }\end{array}$ & 10,628 & 580 & 413 & 0.05 & 34 \\
\hline Assis Brasil & 4972 & 391 & 144 & 0.08 & 11 \\
\hline $\begin{array}{l}\text { Mâncio } \\
\text { Lima }\end{array}$ & 5481 & 355 & 92 & 0.06 & 7 \\
\hline $\begin{array}{c}\text { Porto Walter } \\
\text { Marechal }\end{array}$ & 6466 & 154 & 97 & 0.02 & 7 \\
\hline $\begin{array}{l}\text { Thau- } \\
\text { maturgo }\end{array}$ & 8216 & 86 & 58 & 0.01 & 4 \\
\hline Jordão & 5367 & 61 & 58 & 0.01 & 4 \\
\hline $\begin{array}{c}\text { Santa Rosa } \\
\text { do Purus }\end{array}$ & 6144 & 60 & 7 & 0.01 & 1 \\
\hline Total & 164,240 & 19,620 & 7665 & & \\
\hline
\end{tabular}

\subsection{Distribution of Roads among Land-Tenure Categories in Acre}

The Settlement Projects have the largest total extension of roads in Acre, $7032 \mathrm{~km}$, or $36 \%$ of the state total, followed by Private Properties and Public Lands, $5818 \mathrm{~km}$ and $30 \%$, and $5187 \mathrm{~km}$ and 26\%, respectively (Figure 4A). The increase between 2007 and 2019 was largest in Private Properties, followed by Settlement Projects, Public Lands, Conservation Units (CUs), and Indigenous Lands (ILs). However, the highest percentage of increase between 2007 and 2019, considering the number of roads until 2006, was in Conservation Units, with an increase of $240 \%$. The CU with the highest increase in roads was the Chico Mendes Extractive Reserve, representing 73\% of the 2007-2019 total increase of roads in Conservation Units (Supplementary Material Table S2). The IL has the shortest extension of roads, with $72 \mathrm{~km}$, occurring in the IL along the BR-364 highway, such as the IL Campinas Katukina and IL Katukina/Kaxinawá (Supplementary Material Table S3). 

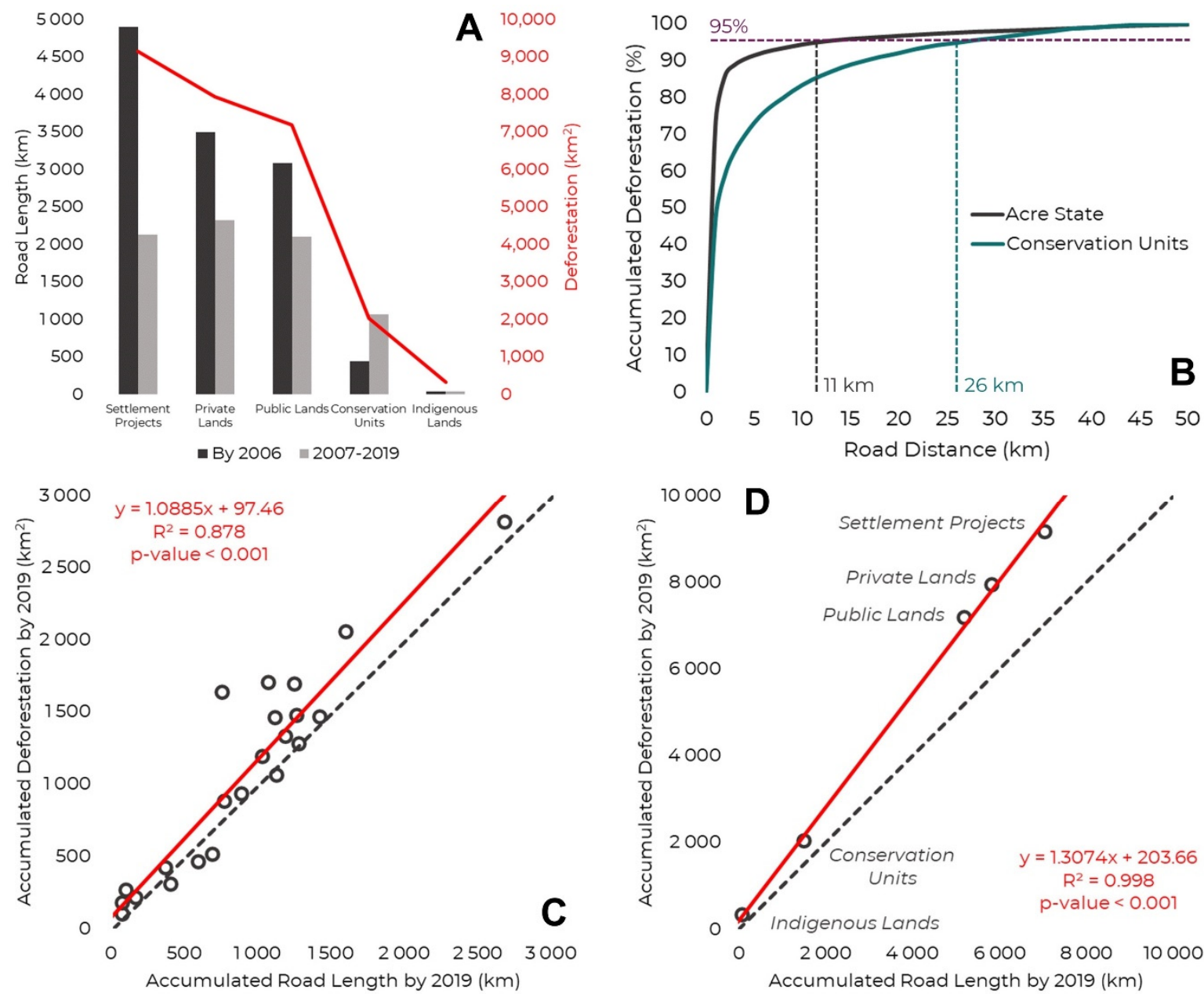

Figure 4. (A) Roads and land class relations in Acre. (B) Percentage accumulation of total deforestation until 2019 for the State of Acre and Conservation Units as a function of distance from the road axes. Dashed lines indicate the distance from the road when $95 \%$ of deforestation accumulates for each unit, black line-State of Acre, and green line-Conservation Units. (C) Relationship between road extension until 2019 with deforestation until 2019 in the State of Acre. Each point represents a municipality. (D) Relationship between road extension until 2019 with deforestation by land class until 2019. The dashed black line in Figure 4C,D is the 1:1 line.

\subsection{Deforestation and Roads}

Of the $23,350 \mathrm{~km}^{2}$ of total deforestation in Acre by 2019 [11], 50\% is concentrated within $1 \mathrm{~km}$ of the all-road axis and $95 \%$ is concentrated within $11 \mathrm{~km}$ (Figure 4B). In Conservation Units, the distance from road axes increases to $2 \mathrm{~km}$ for $50 \%$ of the deforestation and $26 \mathrm{~km}$ for $95 \%$. Correlation analysis showed a decrease in deforestation with an increase in distance from roads $\left(\mathrm{r}^{2}=0.99\right)$.

There was a strong positive correlation between the total deforestation and the total roads in the State of Acre, using the municipality limits as the sample unit $\left(\mathrm{r}^{2}=0.88\right.$, $p$-value $<0.001$, Spearman Correlation; Figure 4C). The municipalities with the largest extension of roads, such as Rio Branco, Sena Madureira, and Xapuri, are the municipalities with large, deforested areas up to 2019. However, in some municipalities, such as Tarauacá and Feijó, which concentrate deforestation along their navigable rivers, such a relationship does not hold.

Analyzing the correlation between deforestation and the extension of roads by land tenure, we observed a positive correlation $\left(\mathrm{r}^{2}=0997, p\right.$-value $<0.001$, Spearman Correlation; Figure 4D). The land tenure project class has the largest deforested area and the most considerable extension of roads. 


\section{Discussion}

\subsection{Road Mapping in the Southwestern Amazon: Advances and Limitations}

This study presents, for the first time for the entire State of Acre, the temporal and spatial construction of road emergence between 2007 and 2019. Similar studies were carried out by Brandrão Jr and Souza Jr [13] for part of Pará and by the Institute of Man and Environment of the Amazon (Imazon-Instituto do Homem e Meio Ambiente da Amazônia) for the entire Amazon Biome. This is an important database, as it allows for an understanding of the dynamics of the roads, such as the rate of growth of the road network annually and the places where this has been occurring, in addition to more detailed analysis, such as the relationships between the roads and changes in the road land use and coverage.

However, it is necessary to proceed with new remote sensing studies that improve the detection of roads. Our study mapped the roads when they were visible in satellite images with a spatial resolution of $30 \mathrm{~m}$, requiring roads close to deforested areas to be detected. The dynamics of opening or building unofficial roads can occur through narrow paths and forest areas that make detection difficult, requiring high-resolution images and improved image processing techniques $[16,17]$. Some recent studies have shown that Deep Learning techniques can automatically extract roads from high spatial resolution satellite images with high accuracy $[14,25]$. However, few studies have applied these techniques in the Amazon.

\subsection{Increase in Roads in the Southwestern Amazon}

At the western end of the Arc of Deforestation, in the State of Acre, $590 \mathrm{~km}_{\text {year }}{ }^{-1}$ of roads are built, equivalent to the opening of a BR-319 highway every 1.5 years, representing $3 \%$ of the opening of new roads in the Amazon [19]. In the last 12 years (2007-2019), the road network has increased by 39\%, centered in the State's eastern and central region, and expanding agricultural frontier. The deforestation arc expansion is underway, a dynamic that concentrates on the emergence of unofficial roads [19]. A downward trend was observed in the annual growth rates of roads up to 2018; however, 2019 had the highest growth in the analyzed time series. This explosion in the appearance of roads is directly related to the significant increase in deforestation in Acre and the entire Amazon [21].

To understand the current spatial distribution of roads in the state of Acre, it is necessary to rescue the historical occupation process. Human occupation occurred from east to west of Acre state. In the east region, where the state capital, Rio Branco, is located, was quantified the highest spatial density of roads and $72 \%$ of all roads in Acre, from the connection with BR-364 that connects it with other Brazilian states. This region has the majority of economic activities, with an emphasis on agricultural enterprises and the largest and oldest settlement projects. The western region where the second-largest city in the state is located, Cruzeiro do Sul, had its occupation history formed mainly by the Juruá river, and until the end of the 2000s, the BR-364, which cuts the state from east to west, did not have traffic for several months of the year. The western region occupied only $12 \%$ of all roads.

Ahmed et al. [19] show that the highest growth rates in the extension of roads in the Brazilian Amazon are along the Arc of Deforestation. Currently, we have 11 municipalities with growth rates greater than $0.019 \mathrm{~km} \mathrm{~km}^{-2}$ year $^{-1}$. In Acre, road expansion occurs from existing roads, mainly linked to federal highways such as BR-364 and BR-317. However, even in municipalities with access only by river and air, such as Porto Walter, Santa Rosa do Purus, and Jordão, there was road construction to connect communities. The most striking example is the municipality of Jordão, which, until 2006, had $3 \mathrm{~km}$ of roads, and then expanded its road network to $58 \mathrm{~km}$ between 2007 and 2019. In 2019, there is no municipality without roads detected, even those where access is fluvial or aerial. The expansion of roads in isolated municipalities raises concerns about the lack of government planning and monitoring, which will lead to deforestation and uncontrolled forest fragmentation, real estate speculation, extractive logging operations, increased risk 
of fire, and loss of biodiversity and carbon, without guaranteeing economic and social development for the region [9,26-33].

In all land categories, $92 \%$ of the roads are in settlement projects, private properties, and public lands. The high growth of roads in public lands is a result of disorderly and uncontrolled occupation. The expansion of roads in Conservation Units is a warning, even though it represents only $8 \%$ of the roads in the State; in the last 12 years, the growth of roads was $240 \%$ compared with the existing roads up to 2006 . This result raises concerns about the future of Conservation Units if monitoring and control strategies are not implemented, such as Reducing Emissions from Deforestation and Forest Degradation (REDD) policies and National, State, and Municipal Plans for deforestation control [9]. Just in the Chico Mendes Extractive Reserve, the increase in roads was $400 \%$ in the period analyzed, representing $73 \%$ of all extensions mapped in CUs across the State; dynamics that may have explanations in the expansion of pasture areas and reduction of forest product chairs, chestnut and rubber [34]. This reflects the pressure that CUs in the Amazon have been experiencing over time.

The primary justification for the construction and paving of roads in the Amazon is economic development, as occurred with the BR-319, BR-163, Inter-Oceanic Highway, and Cruzeiro do Sul-Pucallpa Highway, where the latter has its planned route passing through the Serra do Divisor National Park [35-39]. However, the lack of governance over the expansion of road networks in the Amazon from major highways is influenced by real estate speculation and commodity markets, neglecting environmental and socioeconomic impacts on a local and regional scale [12,28,39]. Vilela et al. [28] note that $45 \%$ of the Amazon roads will generate economic losses without considering the social and environmental externalities. Their study, however, analyzed only the major road infrastructure projects and a complete analysis needs to include small roads, such as those mapped by this study.

\subsection{Roads and Deforestation}

As in other studies, we found a high correlation between roads and deforestation $[9,11,26,28]$. For large highways, studies show that the influence of roads on deforestation can extend up to $50 \mathrm{~km}[10,11]$. However, in Acre, $90 \%$ of the State's deforestation is within $4 \mathrm{~km}$ of the road axes. This result is similar to that pointed out by Barber et al. [9], showing that $95 \%$ of deforestation in the Amazon is concentrated within $5.5 \mathrm{~km}$ of official and unofficial roads.

This pattern also occurs when we analyze the relationship using the land classes as a sample unit. The land tenure classes, Indigenous Lands and Conservation Units, had the lowest deforestation ratio to roads, corroborating studies that show protected areas as a barrier to deforestation [9,40-42]. Land grabbing and land speculation in public lands aggravate the uncontrolled expansion of deforestation [43]. Deforestation across the Brazilian Amazon and the State of Acre in 2019 was the highest since 2008 [21]. Such tendencies are serving to pressure institutions to dismember protected areas or withdraw their protected status [44,45].

The strong association between roads and deforestation shows the importance of the continuous monitoring of roads, which should be one of the factors to be included in State and National plans to combat Deforestation. The State of Acre stands out among the states of the Amazon for its environmental policies, such as the State Plan to Combat Deforestation (PPCD-AC-Plano Estadual de Prevenção e Controle do Desmatamento do Acre) and the Incentive System for Environmental Services (SISA-Sistema de Incentivos a Serviços Ambientais); however, none of them includes road monitoring.

The deforestation policy may have influenced the increase in deforestation and new roads under the presidential administration that began in January 2019. The current federal administration has weakened institutional enforcement capacity, resorting to an emergency approach to environmental policy [3,46-48]. The combination of concrete institutional changes and anti-environmental discourse encourages both deforestation and road building. 


\section{Conclusions}

The official and unofficial roads must be continuously monitored as land access routes have determined the legal, and mainly illegal, deforestation fronts in the Amazon. The application of remote sensing techniques is critical for monitoring illicit environmental activities. Consequently, the dataset produced in this study will be a valuable basis for the validation of future road maps generated by automatic algorithms in the Amazon region.

Within the scope of this research, we observed that in recent years there had been a tendency to decrease the rate of expansion of unofficial roads in Acre, with a change in this pattern and greatly increased extension of unofficial roads in 2019. In the State of Acre, there is no municipality without roads, which shows the need for constant monitoring of road expansion to improve environmental and social control actions.

It is well known that there is a strong relationship between deforestation and roads, where $90 \%$ of deforestation in the entire State is within $4 \mathrm{~km}$ of road axes. Around $92 \%$ of roads are in the land categories that also concentrate deforestation: Settlement Projects, Private Properties, and Public Lands. We highlight the concern of the increase of roads in Conservation Units, where in the last 12 years the growth of roads was $240 \%$ compared with the existing roads up to 2006 .

Supplementary Materials: The following are available online at https://www.mdpi.com/2073-445 X/10/2/106/s1. Supplementary Table S1. Images from the Landsat satellite used to identify and map roads in the State of Acre, Table S2. The 10 Conservation Units with greatest length of roads in the state of Acre, Table S3. The 10 Indigenous Lands (ILs) with greatest length of roads in the state of Acre.

Author Contributions: Conceptualization, data, and writing —original draft preparation, E.d.S.N. and S.S.d.S.; Writing—review, L.B., A.W.F.d.M., and C.H.L.S.J.; Writing—review and analysis, A.B.J., C.M.S.J. and C.H.L.S.J. All authors have read and agreed to the published version of the manuscript.

Funding: This study was financed in part by the Coordenação de Aperfeiçoamento de Pessoal de Nível Superior - Brasil (CAPES) - Finance Code 001. We are grateful for CNPq/Prevfogo-Ibama ${ }^{\circ}$ 33/2018 AcreQueimadas Project, FAPAC N ${ }^{\circ}$ 03/2013 and Universidade Federal do Acre/CAPES.

Institutional Review Board Statement: Not applicable.

Informed Consent Statement: Not applicable.

Data Availability Statement: The data that support the findings of this study are all publicly available from their sources. Processed data, products and code produced in this study are available from the corresponding author upon reasonable request.

Acknowledgments: We thank the scientists at the National Institute for Space Research (INPE) for providing the freely available datasets used in this study. We also thank the three reviewers for their insightful feedback on the manuscript. Finally, we thank Foster Brown for language editing.

Conflicts of Interest: The authors declare no conflict of interest.

\section{References}

1. Barni, P.E.; Fearnside, P.M.; Graça, P.M.L.d.A. Simulating Deforestation and Carbon Loss in Amazonia: Impacts in Brazil's Roraima State from Reconstructing Highway BR-319 (Manaus-Porto Velho). Environ. Manag. 2014, 55, 259-278. [CrossRef] [PubMed]

2. Laurance, W.F.; Albernaz, A.K.M.; Schroth, G.; Fearnside, P.M.; Bergen, S.; Venticinque, E.M.; Da Costa, C. Predictors of Deforestation in the Brazilian Amazon. J. Biogeogr. 2002, 29, 737-748. [CrossRef]

3. Ferrante, L.; Fearnside, P.M. The Amazon's Road to Deforestation. Science 2020, 369, 634. [CrossRef] [PubMed]

4. Fearnside, P.M. A tomada de decisão sobre grandes estradas amazônicas. In Destruição e Conservação da Floresta Amazônica; INPA: Manaus, Brazil, 2019; Volume 1, pp. 327-337.

5. Fearnside, P.M.; Laurance, W.F. Infraestrutura na Amazônia: As lições dos planos plurianuais. Cad. CRH 2012, 25, 87-98. [CrossRef]

6. Armenteras, D.; Barreto, J.S.; Tabor, K.; Molowny, R.; Retana, J. Changing Patterns of Fire Occurrence in Proximity to Forest Edges, Roads and Rivers between NW Amazonian Countries. Biogeosci. Discuss. 2017, 2017, 1-29. [CrossRef] 
7. Cardille, J.A.; Ventura, S.J.; Turner, M.G. Environmental and Social Factors Influencing Wildfires in the Upper Midwest, United States. Ecol. Appl. 2001, 11, 111-127. [CrossRef]

8. Rivero, S.; Almeida, O.; Ávila, S.; Oliveira, W. Pecuária e desmatamento: Uma análise das principais causas diretas do desmatamento na Amazônia. Nova Econ. 2009, 19, 41-66. [CrossRef]

9. Barber, C.P.; Cochrane, M.A.; Souza, C.M., Jr.; Laurance, W.F. Roads, Deforestation, and the Mitigating Effect of Protected Areas in the Amazon. Biol. Conserv. 2014, 177, 203-209. [CrossRef]

10. Ferreira, L.V.; Venticinque, E.; Almeida, S. O Desmatamento Na Amazônia e a Importância Das Áreas Protegidas. Estud. Av. 2005, 19, 157-166. [CrossRef]

11. Soares-Filho, B.; Alencar, A.; Nepstad, D.; Cerqueira, G.; Vera Diaz, M.d.C.; Rivero, S.; Solórzano, L.; Voll, E. Simulating the Response of Land-Cover Changes to Road Paving and Governance along a Major Amazon Highway: The Santarém-Cuiabá Corridor. Glob. Chang. Biol. 2004, 10, 745-764. [CrossRef]

12. Fearnside, P.M.; Graça, P.M.L.d.A. BR-319: Brazil's Manaus-Porto Velho Highway and the Potential Impact of Linking the Arc of Deforestation to Central Amazonia. Environ. Manag. 2006, 38, 705-716. [CrossRef] [PubMed]

13. Brandão, A.O., Jr.; Souza, C.M., Jr. Mapping Unofficial Roads with Landsat Images: A New Tool to Improve the Monitoring of the Brazilian Amazon Rainforest. Int. J. Remote Sens. 2006, 27, 177-189. [CrossRef]

14. Lian, R.; Wang, W.; Mustafa, N.; Huang, L. Road Extraction Methods in High-Resolution Remote Sensing Images: A Comprehensive Review. IEEE J. Sel. Top. Appl. Earth Obs. Remote Sens. 2020, 13, 5489-5507. [CrossRef]

15. Maboudi, M.; Amini, J.; Malihi, S.; Hahn, M. Integrating Fuzzy Object Based Image Analysis and Ant Colony Optimization for Road Extraction from Remotely Sensed Images. ISPRS J. Photogramm. Remote Sens. 2018, 138, 151-163. [CrossRef]

16. Hinz, S.; Baumgartner, A. Automatic Extraction of Urban Road Networks from Multi-View Aerial Imagery. ISPRS J. Photogramm. Remote Sens. 2003, 58, 83-98. [CrossRef]

17. Li, Y.; Briggs, R. Automatic Extraction of Roads from High Resolution Aerial and Satellite Images with Heavy Noise. Int. J. Comput. Inf. Eng. 2009, 3, 1571-1577.

18. Kleinschroth, F.; Laporte, N.; Laurance, W.F.; Goetz, S.J.; Ghazoul, J. Road Expansion and Persistence in Forests of the Congo Basin. Nat. Sustain. 2019, 2, 628-634. [CrossRef]

19. Ahmed, S.E.; Souza, C.M.; Riberio, J.; Ewers, R.M. Temporal Patterns of Road Network Development in the Brazilian Amazon. Reg. Environ. Chang. 2013, 13, 927-937. [CrossRef]

20. Nascimento, E.d.S.; de Almeida, M.R.N.; Souza, G.d.C.; Silva, S.S. Dinâmica Da Expansão de Estradas e Desmatamento No Município de Cruzeiro Do Sul, Acre, Brazil; GALOÁ: Campinas, Brazil, 2019; Volume 17.

21. Inpe. Project PRODES-Monitoring of the Brazilian Amazon Forest by Satellite. 2020. Available online: http://www.obt.inpe.br/ prodes/ (accessed on 21 January 2021).

22. Congalton, R.G.; Green, K. Assessing the Accuracy of Remotely Sensed Data: Principles and Practices, 2nd ed.; CRC Press: Boca Raton, FL, USA, 2008; ISBN 978-0-429-14397-7.

23. Acre. Zoneamento Ecológico-Econômico Do Estado Do Acre: Fase II (Escala 1:250.000), 2nd ed.; SEMA: Rio Branco, Brazil, 2010.

24. Ibge. Municipal Boundaries Limits. 2016. Available online: https://mapas.ibge.gov.br/bases-e-referenciais/bases-cartograficas/ malhas-digitais.html (accessed on 21 January 2021).

25. Zhang, Z.; Liu, Q.; Wang, Y. Road Extraction by Deep Residual U-Net. IEEE Geosci. Remote Sens. Lett. 2018, 15, 749-753. [CrossRef]

26. Fearnside, P.M. Brazil's Cuiabá- Santarém (BR-163) Highway: The Environmental Cost of Paving a Soybean Corridor Through the Amazon. Environ. Manag. 2007, 39, 601. [CrossRef]

27. Laurance, S.G.W.; Stouffer, P.C.; Laurance, W.F. Effects of Road Clearings on Movement Patterns of Understory Rainforest Birds in Central Amazonia. Conserv. Biol. 2004, 18, 1099-1109. [CrossRef]

28. Vilela, T.; Harb, A.M.; Bruner, A.; Arruda, V.L.d.S.; Ribeiro, V.; Alencar, A.A.C.; Grandez, A.J.E.; Rojas, A.; Laina, A.; Botero, R. A Better Amazon Road Network for People and the Environment. Proc. Natl. Acad. Sci. USA 2020, 117, 7095-7102. [CrossRef] [PubMed]

29. Silveira, M.V.F.; Petri, C.A.; Broggio, I.S.; Chagas, G.O.; Macul, M.S.; Leite, C.C.S.S.; Ferrari, E.M.M.; Amim, C.G.V.; Freitas, A.L.R.; Motta, A.Z.V.; et al. Drivers of Fire Anomalies in the Brazilian Amazon: Lessons Learned from the 2019 Fire Crisis. Land 2020, 9 , 516. [CrossRef]

30. Silva Junior, C.H.L.; Aragão, L.E.O.C.; Anderson, L.O.; Fonseca, M.G.; Shimabukuro, Y.E.; Vancutsem, C.; Achard, F.; Beuchle, R.; Numata, I.; Silva, C.A.; et al. Persistent Collapse of Biomass in Amazonian Forest Edges Following Deforestation Leads to Unaccounted Carbon Losses. Sci. Adv. 2020, 6, eaaz8360. [CrossRef] [PubMed]

31. Silva Junior, C.; Aragão, L.; Fonseca, M.; Almeida, C.; Vedovato, L.; Anderson, L. Deforestation-Induced Fragmentation Increases Forest Fire Occurrence in Central Brazilian Amazonia. Forests 2018, 9, 305. [CrossRef]

32. Bullock, E.L.; Woodcock, C.E.; Souza, C.; Olofsson, P. Satellite-based Estimates Reveal Widespread Forest Degradation in the Amazon. Glob. Chang. Biol. 2020, 26, 2956-2969. [CrossRef]

33. Matricardi, E.A.T.; Skole, D.L.; Costa, O.B.; Pedlowski, M.A.; Samek, J.H.; Miguel, E.P. Long-Term Forest Degradation Surpasses Deforestation in the Brazilian Amazon. Science 2020, 369, 1378-1382. [CrossRef]

34. Gomes, C.V.A.; Perz, S.G.; Vadjunec, J.M. Convergence and Contrasts in the Adoption of Cattle Ranching: Comparisons of Smallholder Agriculturalists and Forest Extractivists in the Amazon. J. Lat. Am. Geogr. 2012, 11, 99-120. [CrossRef] 
35. Jardim, A. Estrada Do Pacífico Integra Economia e Cultura Com o Peru. 2013. Available online: https://agencia.ac.gov.br/ estrada-do-pacifico-integra-economia-e-cultura-com-o-peru/ (accessed on 21 January 2021).

36. Liberato, G., Jr. BR-319 Vai Impulsionar a Economia. 2017. Available online: https://www.diariodaamazonia.com.br/br-319-vaiimpulsionar-economia/ (accessed on 21 January 2021).

37. Silva, A. Acre e Peru Assinam Declaração de Interesse Pela Construção de Rodovia. 2019. Available online: https://agencia.ac. gov.br/aacre-e-peru-assinam-declaracao-de-interesse-pela-construcao-de-rodovia / (accessed on 21 January 2021).

38. Valdes, A. Conclusão Da BR-163, Um Sonho Realizado. 2020. Available online: https://valor.globo.com/agronegocios/noticia/ 2020/03/19/conclusao-da-br-163-um-sonho-realizado.ghtml (accessed on 21 January 2021).

39. Baraloto, C.; Alverga, P.; Quispe, S.B.; Barnes, G.; Chura, N.B.; da Silva, I.B.; Castro, W.; da Souza, H.; de Souza Moll, I.E.; Del Alcazar Chilo, J.; et al. Effects of Road Infrastructure on Forest Value across a Tri-National Amazonian Frontier. Biol. Conserv. 2015, 191, 674-681. [CrossRef]

40. Pfaff, A.; Robalino, J.; Lima, E.; Sandoval, C.; Herrera, L.D. Governance, Location and Avoided Deforestation from Protected Areas: Greater Restrictions Can Have Lower Impact, Due to Differences in Location. World Dev. 2014, 55, 7-20. [CrossRef]

41. Nolte, C.; Agrawal, A. Linking Management Effectiveness Indicators to Observed Effects of Protected Areas on Fire Occurrence in the Amazon Rainforest. Conserv. Biol. 2013, 27, 155-165. [CrossRef]

42. Pfaff, A.; Robalino, J.; Herrera, D.; Sandoval, C. Protected Areas' Impacts on Brazilian Amazon Deforestation: Examining Conservation-Development Interactions to Inform Planning. PLoS ONE 2015, 10. [CrossRef] [PubMed]

43. Stabile, M.C.C.; Guimarães, A.L.; Silva, D.S.; Ribeiro, V.; Macedo, M.N.; Coe, M.T.; Pinto, E.; Moutinho, P.; Alencar, A. Solving Brazil's Land Use Puzzle: Increasing Production and Slowing Amazon Deforestation. Land Use Policy 2020, 91, 104362. [CrossRef]

44. Keles, D.; Delacote, P.; Pfaff, A.; Qin, S.; Mascia, M.B. What Drives the Erasure of Protected Areas? Evidence from across the Brazilian Amazon. Ecol. Econ. 2020, 176, 106733. [CrossRef]

45. Paiva, P.F.P.R.; Ruivo, M.d.L.P.; Silva Júnior, O.M.; Maciel, M.d.N.M.; Braga, T.G.M.; Andrade, M.M.N.; Santos Junior, P.C.; Rocha, E.S.; Freitas, T.P.M.; Leite, T.V.d.S.; et al. Deforestation in Protect Areas in the Amazon: A Threat to Biodiversity. Biodivers. Conserv. 2020, 29, 19-38. [CrossRef]

46. Abessa, D.; Famá, A.; Buruaem, L. The Systematic Dismantling of Brazilian Environmental Laws Risks Losses on All Fronts. Nat. Ecol. Evol. 2019, 3, 510-511. [CrossRef] [PubMed]

47. Ferrante, L.; Fearnside, P.M. Brazil's New President and 'Ruralists' Threaten Amazonia's Environment, Traditional Peoples and the Global Climate. Environ. Conserv. 2019, 46, 261-263. [CrossRef]

48. Pereira, E.J.d.A.L.; Ferreira, P.J.S.; Ribeiro, L.C.d.S.; Carvalho, T.S.; Pereira, H.B.d.B. Policy in Brazil (2016-2019) Threaten Conservation of the Amazon Rainforest. Environ. Sci. Policy 2019, 100, 8-12. [CrossRef] 